\title{
Technical evaluation and optimization of biological aerated filter (BAF) treating micro-polluted source water at low temperature
}

\author{
Dongmei $\mathrm{Liu}^{1 \dagger}$, Xin Wang ${ }^{1}$, Xiaobo $\mathrm{Li}^{2}$, Aiwen Wang ${ }^{1}$ \\ ${ }^{1}$ State Key Laboratory of Urban Resource and Environment(SKLUWRE),School of Environment, Harbin Institute of Technology, Harbin 150090, PR China \\ ${ }^{2}$ Hangzhou Nandu Power Technology Co. LTD, Hangzhou 311100, PR China
}

\begin{abstract}
In this study, polyethylene and zeolite, as media in two-stage biological aerated filters (BAF), were evaluated for simultaneous removal of ammonia nitrogen and organics in micro-polluted water under low temperature conditions. For specific source water, the contaminants removal characteristics are evaluated by single-factor experiment to determine the suitable $\mathrm{pH}$, air-water ratio (AWR) and hydraulic load ratio (HLR). Ammonia nitrogen and permanganate index in BAFs were promoted effectively with $\mathrm{pH}=7 \sim 8, \mathrm{AWR}=1.0: 1.0 \sim 2.0: 1.0, \mathrm{HLR}=1 \sim 4 \mathrm{~m}^{3} /\left(\mathrm{m}^{2} \cdot \mathrm{h}\right)$, low pollution loads and a temperature of $10^{\circ} \mathrm{C}$. Based on the response surface analysis, the optimum parameters were as follows: $\mathrm{pH}$ of 7.94, AWR of 1.41:1.0 and HLR of $1.39 \mathrm{~m}^{3} /\left(\mathrm{m}^{2} \cdot \mathrm{h}\right)$, for simultaneous removal of ammonia nitrogen and permanganate index, their removal rates were respectively $59.76 \%$ and $18.16 \%$. BAF has a great advantage in emergency treatment of low temperature micro-polluted water, and response surface analysis can be used to optimize operating parameters.
\end{abstract}

Keywords: BAF, Emergency treatment, Low temperature, Micro-polluted water, Response surface methodology

\section{Introduction}

In northern China, there is a 3-5 month freezing period with low temperature water every year [1]. The low nitrogen and organic content of micro-polluted water results in low purification efficiency. This has been a challenge for China and other countries, it is difficult to ensure the stability of the effluent water quality to meet the standards by the conventional treatment process.

Biological aerated filter (BAF) is a new type of biofilm reactor, which integrates the interception of suspended solids and biological oxidation [2-7]. The existing research shows that BAF is used to deal with micro-polluted water treatment with high efficiency, small occupation of land, little investment and low operating cost [8-10]. Meanwhile, a lot of research show that conventional biological aerated filter and new biological aerated filter can degrade organic matter in wastewater and remove ammonia nitrogen [11]. Temperature is one of the important factors affecting BAF [12, 13]. BAF has been widely used in the emergency treatment of micro-polluted source water in normal temperature water [14], but there is still a lack of practical research and operational manage- ment experience for low temperature water.

In this paper, the treatment characteristics of ammonia nitrogen and organics in micro-polluted water in the different conditions were examined. The parameters of BAF were optimized and the regression model was analyzed by response surface method, in order to discuss the emergency applicability of BAF at low temperature, and the optimization of the operation parameters for design and operational management use.

\section{Materials and Methods}

\subsection{Equipment}

A lab-scale BAF made of a polymethyl methacrylate, with a wall thickness of $5 \mathrm{~mm}$, a height of $1.8 \mathrm{~m}$ and internal diameter of $150 \mathrm{~mm}$ was used in this study (Fig. 1). The working volume of the reactor was $30 \mathrm{~L}$, in which about $10 \mathrm{~L}$ was filled with natural zeolite in the upper layer and $10 \mathrm{~L}$ polyethylene in the lower layer as the biomass carriers. Water was fed to the reactor using a peristaltic pump with continuous feeding, fully mixing with the
This is an Open Access article distributed under the terms of the Creative Commons Attribution Non-Commercial License (http://creativecommons.org/licenses/by-nc/3.0/) which permits unrestricted non-commercial use, distribution, and reproduction in any medium, provided the original work is properly cited.

Copyright (C) 2022 Korean Society of Environmental Engineers
Received April 02, 2021 Accepted May 30, 2021

${ }^{\dagger}$ Corresponding author

E-mail: ldm819@126.com

Tel: +86-451-26283006 Fax: +86-451-26283006

ORCID: 0000-0002-2056-8600 


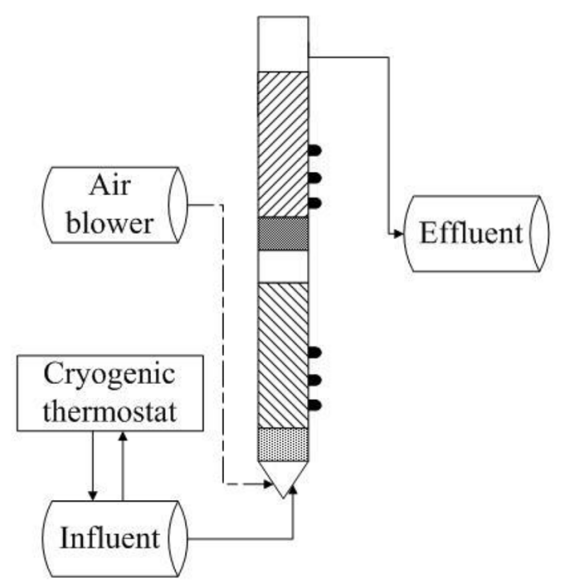

\section{QIIIT Zeolite \\ MIIV Polyethylene \\ Retainer layer \\ Sampling}

Fig. 1. Schematic diagram of BAF device.

air in the bottom. The reactor was controlled with a cryogenic thermostat to control the temperature of the liquid flowed between $10 \pm 1^{\circ} \mathrm{C}$. The air was pumped to BAF by an air blower with gas flow. The upper and lower parts of the reaction column shall be provided with a sampling port to facilitate water sample collection.

\subsection{Water Characteristics}

According to the condition of micro-pollution, the water used in this study comes from a river in northern China. The parameters of water sample are shown in Table 1. In the $\mathrm{pH}$ single factor experiment, the phosphate buffer solution was used to adjust the $\mathrm{pH}$.

Table 1. Characteristics of Water

\begin{tabular}{lccc}
\hline $\begin{array}{l}\text { Ammonia } \\
(\mathrm{mg} / \mathrm{L})\end{array}$ & $\begin{array}{c}\text { Permanganate index } \\
(\mathrm{mg} / \mathrm{L})\end{array}$ & $\mathbf{p H}$ & $\begin{array}{c}\text { Temperature } \\
\left({ }^{\circ} \mathrm{C}\right)\end{array}$ \\
\hline $0.24-2.61$ & $2.12-7.47$ & $6.0-8.5$ & 10 \\
\hline
\end{tabular}

\subsection{Experimental Set-up}

The seed sludge was obtained from an aeration unit of biological process in our laboratory. Firstly, the BAF was inoculated with seed sludge and aerated for $3 \mathrm{~d}$ to grow biofilm. Afterwards, ammonia and permanganate index should be reduced gradually and the flow rate should be increased gradually with high concentration of pollutants, until the average concentration of $2 \mathrm{mg} / \mathrm{L}$ $\mathrm{NH}_{4}{ }^{+}-\mathrm{N}$, permanganate index was of 5-8 mg/L. Finally the operation should be continued until the reactor operation was stable. Samples were taken to measure ammonia and permanganate index of the effluent at the same time everyday during the start-up process. When the removal rate of ammonia reached more than $60 \%$, the reactor was considered successful. The entire start-up phase lasted about $30 \mathrm{~d}$.

\subsection{Analytical Methods}

Ammonium was analyzed by Nessler's reagent spectrophotometer method, permanganate index according to Chinese standard exami- nation of water and wastewater [15]. DO and temperature were measured using a digital DO meters (JPSJ-605, Shanghai Leici Co., Ltd, China), and $\mathrm{pH}$ was tested by $\mathrm{pH}$ meter (PHS-3C, INESA Scientifi c Instrument Co. Ltd, China). The results were the mean of three tests per day (a total of three parallel trials).

\section{Results and Discussion}

\subsection{Effect of $\mathrm{pH}$ on Pollutants Removal}

The influence of $\mathrm{pH}$ on the pollutant removal was investigated under the conditions of influent flow of $10 \mathrm{~L} / \mathrm{h}$, AWR of 1.0:1.0 and hydraulic load of $2 \mathrm{~m}^{3} /\left(\mathrm{m}^{2} \cdot \mathrm{h}\right)$. Fig. 2 shows the removal rates for pollutants at different $\mathrm{pH}$.

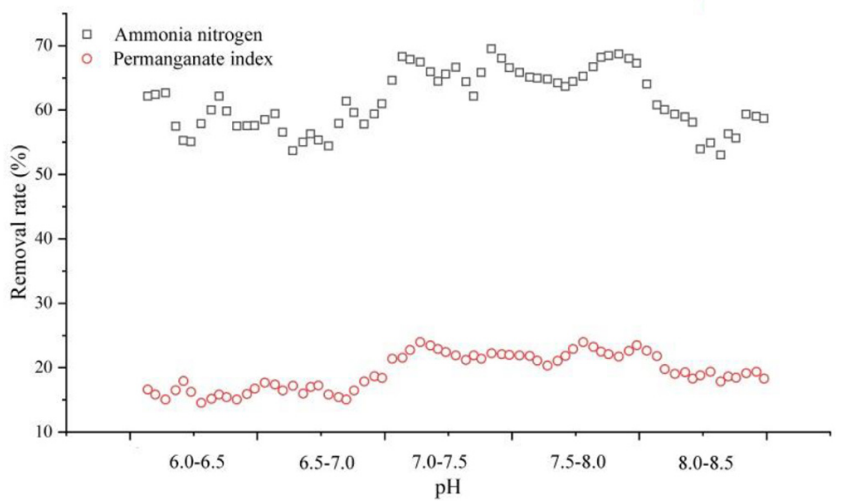

Fig. 2. Effect of $\mathrm{pH}$ on the pollutants removal.

With the $\mathrm{pH}$ changed from 6.0 to 7.5 , the removal rate of $\mathrm{NH}_{4}{ }^{+}-\mathrm{N}$ gradually increased as it became closer to the optimal $\mathrm{pH}$ for the growth of nitrifying bacteria. Nitrite bacteria are suitable to live in neutral or weakly alkaline environment. When the environmental $\mathrm{pH}$ is less than 6 , the metabolism of nitrite bacteria will be seriously affected and even threatened to stagnate. Otherwise, ambient $\mathrm{pH}$ is greater than 9.6, the bacteria will also be unable to survive and play biological activities due to the alkaline condition [16]. As nitrifying bacteria are suitable for living in weakly alkaline environment, the ammonia nitrogen purification effect of the reactor is excellent in the $\mathrm{pH}$ range of 7.1-8.0. Although nitrification was affected to a certain extent due to the increase of $\mathrm{pH}$ in the range of 8.1-8.5, it still showed adaptability to $\mathrm{pH}$.

With the $\mathrm{pH}$ changed from 6.0 to 7.5, the removal rate of permanganate index gradually increased, too. But in the process of $\mathrm{pH}$ changing, the purification effect of BAF on the permanganate index changed little, fluctuating around 15\%, which indicated that the foreign bacteria removing permanganate index had strong adaptability to $\mathrm{pH}$. Peak purification of permanganate index occurred between pH 7.0 to 8.0. The weakly alkaline environment was suitable for the survival of corresponding heterotrophic microorganisms.

\subsection{Effect of Air Gas Ratio (AWR) on Pollutants Removal}

The influence of AWR on the pollutants removal was investigated under the conditions of influent flow of $10 \mathrm{~L} / \mathrm{h}, \mathrm{pH}$ of 8 and HLR 
of $2 \mathrm{~m}^{3} /\left(\mathrm{m}^{2} \cdot \mathrm{h}\right)$. These results suggest that AWR impacts the ammonia and permanganate index removal. DO in the water increases as AWR increases, BAF should maintain a certain concentration of DO to facilitate bacterial grow for water purification, otherwise, the rate of biochemical reactions will be affected by the limitations. Therefore, it is very important to choose the appropriate air-water ratio for the stable operation of the biological aerated filter. Fig. 3 shows the removal rates for two pollutants at different AWR from 0.5:1.0-2.0:1.0

For the removal of ammonia, when AWR increased from 0.5:1.0 to 1.0:1.0, removal rate showed a leap forward growth. AWR was mainly consumed by heterotrophic bacteria in the outer layer of microbial membrane with low AWR (0.5:1.0), and this condition limited the growth of nitrifying bacteria in the inner layer of microbial membrane $[17,18]$. This indicated that low DO can only oxidize part of ammonia nitrogen to nitrite nitrogen, and limited the further transformation of nitrite nitrogen to nitrate nitrogen [19]. When AWR increased from 1.0:1.0-2.0:1.0, ammonia removal did not change very much.

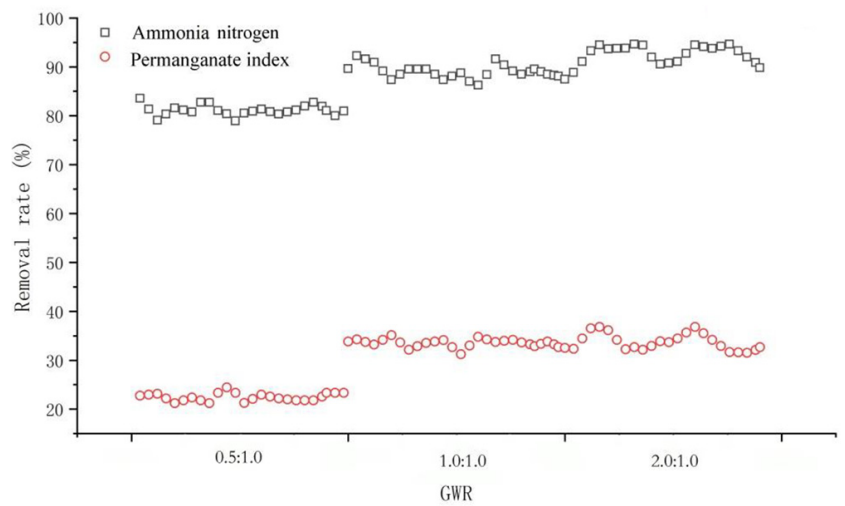

Fig. 3. Effect of AWR on pollutants removal.

In particular, when AWR increased from 0.5:1.0 to 1.0:1.0, removal rate of permanganate index also showed a leap forward growth. Meanwhile as AWR continued to increase, the removal rate slowed down. This condition can be possibly attributed to that AWR increased, thereby promoting the organic degradation by aerobic heterotrophic bacteria [20, 21]. Heterotrophic bacteria in the outer layer of microbial biofilm can be easily separated from carriers. However, excessive AWR will produce strong air shear force, which will disturb the microbial biofilm and lose the biomass of the biofilm. Ultimately, the thickness of the microbial film will decrease. Therefore, 1.0:1.0-2.0:1.0 is an optimum AWR to achieve high pollutant removal rates for both pollutants.

\subsection{Effect of Hydraulic Load Ratio (HLR) on Pollutants Removal}

The influence of HLR on the pollutant removal was investigated under the conditions of influent flow of $10 \mathrm{~L} / \mathrm{h}, \mathrm{pH}$ of 8 and DO of $4 \mathrm{mg} / \mathrm{L}$. The effects of HLR on the ammonia nitrogen concentration and permanganate index in the BAF reactor are shown in Fig. 4. HLR is a process parameter directly related to hydraulic retention time (HRT).
For ammonia nitrogen, an addition in HLR means a reduction in HRT which will lead to higher loads. High load has a certain effect on nitrifying bacteria in BAF, thus affecting the purification effect. The removal efficiency of ammonia nitrogen was approximately $62.32 \%$ with HLR was $1-2 \mathrm{~m}^{3} /\left(\mathrm{m}^{2} \cdot \mathrm{h}\right)$. Increasing the HLR from 3 to $6 \mathrm{~m}^{3} /\left(\mathrm{m}^{2} \cdot \mathrm{h}\right)$, removal efficiency dropped to $38.8 \%$. Due to long HRT, bacteria had sufficient time to degrade and remove pollutants, and BAF showed good purification efficiency for $\mathrm{NH}_{4}{ }^{+} \mathrm{N}$. When HLR increased, although HRT is relatively reduced, the erosion ability and activity of the biofilm was enhanced due to the doubling of the HLR. With the HLR further increasing, the contact time between $\mathrm{NH}^{3}-\mathrm{N}$ and nitrifying bacteria in the biofilm decreases and the water flow has a certain hydraulic shear effect on the biofilm, leading to a significant decrease in the removal rate of $\mathrm{NH}_{4}{ }^{+}-\mathrm{N}$.

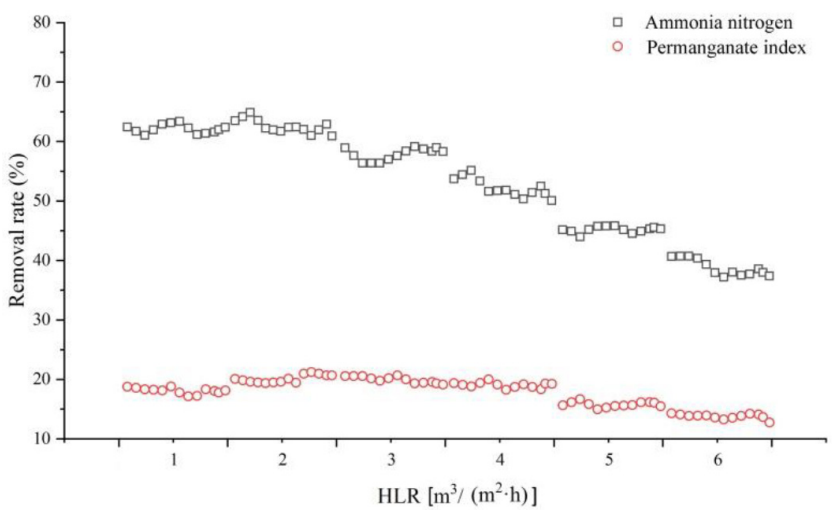

Fig. 4. Effect of HLR on pollutants removal.

Additionally, the removal efficiency of permanganate index was stable and reached its peak, approximately $19.2 \%$, with HLR was $2-4 \mathrm{~m}^{3} /\left(\mathrm{m}^{2} \cdot \mathrm{h}\right)$. Further increase in HLR, reactor purification effect of permanganate index continued to decline, this was because the high HLR, with staying time was too short, insoluble organic matter degradation was directly discharge, and high filtration speed lead to biofilm washed, the biofilm thickness was beyond the scope purification effect, worsen water quality.

\subsection{Response Surface Test Results and Model Analysis}

On the basis of the above single-factor tests, $\mathrm{pH}\left(\mathrm{X}_{1}\right)$, AWR $\left(\mathrm{X}_{2}\right)$ and $\operatorname{HLR}\left(\mathrm{X}_{3}\right)$ were taken as independent variables, and the removal rate of $\mathrm{NH}_{4}{ }^{+}-\mathrm{N}\left(\mathrm{Y}_{1}\right)$ and removal rate of permanganate index $\left(\mathrm{Y}_{2}\right)$ were taken as response values. Response surface Box-Behnken central combination test (using response surface software Design Expert 8.0.5) was used to optimize the BAF. Table 2 shows the factors, horizontal combinations, and response values of the test. Multiple regression analysis was shown in Eq. (1) and Eq. (2) which were the equations of removal rate of $\mathrm{NH}_{4}{ }^{-}-\mathrm{N}$ and removal rate of permanganate index. The correlation coefficients $\mathrm{R}^{2}$ of the equations were 0.9902 and 0.9934 , indicating that the regression model had a good fit with the actual situation and could be used in the optimization test of operational conditions of BAF. Meanwhile, the models $\left(\mathrm{Y}_{1}\right.$ and $\left.\mathrm{Y}_{2}\right)$ have a high significance $(\mathrm{P}$ $<0.0001)$. 
Table 2. Factors and Levels Test and Response Values

\begin{tabular}{cccccc}
\hline NO. & $\mathbf{X}_{\mathbf{1}}$ & $\mathbf{X}_{\mathbf{2}}$ & $\mathbf{X}_{\mathbf{3}} / \mathbf{m}^{\mathbf{3}} / \mathbf{m}^{\mathbf{2}} \cdot \mathbf{h}_{\mathbf{1}}$ & $\mathbf{Y}_{\mathbf{1}} / \mathbf{\%}$ & $\mathbf{Y}_{2} / \mathbf{\%}$ \\
\hline 1 & 7.25 & 1.25 & 3.5 & 58.8 & 18.1 \\
2 & 7.25 & 2 & 1 & 59.0 & 18.2 \\
3 & 8.50 & 1.25 & 6 & 50.6 & 16.6 \\
4 & 7.25 & 1.25 & 3.5 & 58.8 & 18.1 \\
5 & 8.50 & 1.25 & 1 & 58.6 & 17.5 \\
6 & 7.25 & 2 & 6 & 53.9 & 17.8 \\
7 & 7.25 & 0.5 & 1 & 58.7 & 17.3 \\
8 & 6 & 2 & 3.5 & 56.6 & 17.2 \\
9 & 7.25 & 1.25 & 3.5 & 58.8 & 18.1 \\
10 & 7.25 & 0.5 & 6 & 51.3 & 15.7 \\
11 & 8.5 & 0.5 & 3.5 & 54.6 & 16.4 \\
12 & 8.5 & 2 & 3.5 & 57.2 & 16.9 \\
13 & 6 & 1.25 & 6 & 50.5 & 15.9 \\
14 & 7.25 & 1.25 & 3.5 & 58.8 & 18.1 \\
15 & 7.25 & 1.25 & 3.5 & 58.8 & 18.1 \\
16 & 6 & 1.25 & 1 & 58.2 & 17.6 \\
17 & 6 & 0.5 & 3.5 & 54.5 & 15.3 \\
\hline
\end{tabular}

$$
\begin{gathered}
\mathrm{Y}_{1}=-16.29706+20.10533 \mathrm{X}_{1}+3.28222 \mathrm{X}_{2}+ \\
0.80267 \mathrm{X}_{3}+0.13333 \mathrm{X}_{1} \mathrm{X}_{2}-0.024 \mathrm{X}_{1} \mathrm{X}_{2}+ \\
0.30667 \mathrm{X}_{2} \mathrm{X}_{3}-1.384 \mathrm{X}_{1}^{2}-1.62222 \mathrm{X}_{2}^{2}-0.346 \mathrm{X}_{3}^{2} \\
\mathrm{Y}_{2}=-20.13189+9.66267 \mathrm{X}_{1}+5.93556 \mathrm{X}_{2}-0.67 \mathrm{X}_{3}- \\
0.37333 \mathrm{X}_{1} \mathrm{X}_{2}+0.064 \mathrm{X}_{1} \mathrm{X}_{3}+0.16 \mathrm{X}_{2} \mathrm{X}_{3}- \\
0.64 \mathrm{X}_{1}{ }^{2}-1.15556 \mathrm{X}_{2}^{2}-0.32 \mathrm{X}_{3}^{2}
\end{gathered}
$$

According to the quadratic regression equation and regression model variance analysis results, the response surface diagram of $\mathrm{pH}, \mathrm{AWR}, \mathrm{HLR}$, the removal rate of $\mathrm{NH}_{4}{ }^{+}-\mathrm{N}$ and the removal rate of permanganate index was made, and the results were shown in Fig. 5.

It can be seen from Fig. 5(a) that, when AWR was fixed, the removal rate of $\mathrm{NH}_{4}{ }^{+}-\mathrm{N}$ increased first and then decreased with the increasing of $\mathrm{pH}$. However, from the contour line, the interaction between $\mathrm{pH}$ and AWR was not obvious. According to Fig. 5(b), HLR was fixed, the removal rate of $\mathrm{NH}_{4}{ }^{+}-\mathrm{N}$ increased first and then decreased with the increasing of $\mathrm{PH}$, and the interaction was not obvious. From Fig. 5(c), HLR was constant, the removal rate of $\mathrm{NH}_{4}{ }^{+} \mathrm{-N}$ increased first and then tended to be stable with the increase of AWR, and there was an interaction.

From Fig. 5(d), AWR was fixed the removal rate of permanganate index first increased and then decreased with the increasing of $\mathrm{pH}$, and the interaction was obvious. According to Fig. 5(e), when HLR was constant, the removal rate of permanganate index increased first and then decreased with the increasing of $\mathrm{PH}$, and the interaction was not obvious. From Fig. 5(f), when HLR was constant, the removal rate of permanganate index increased and tends to be flat with the increasing of AWR, and the interaction was obvious.

The above changes were consistent with the relevant conclusions in the single-factor test. According to the parameter optimization analysis of the established mathematical model, the optimization conditions of the model were obtained as follows : $\mathrm{pH}$ is 7.94, AWR is $1.41: 1.0$, HLR is $1.39 \mathrm{~m}^{3} /\left(\mathrm{m}^{2} \cdot \mathrm{h}\right)$ at this time, the removal rate of $\mathrm{NH}_{4}{ }^{+} \mathrm{N}$ and permanganate index reached $59.76 \%$, and $18.16 \%$.

Table 3 shows the test results before and after response surface optimization. No. 1 and 2 are the parallel tests after optimization, and No.3 and 4 are the parallel tests before optimization, and the mean values of the two groups of parallel tests are compared. It shows the treatment effect simultaneous ammonia nitrogen and organics removal can be guaranteed on the basis of cost saving and land reduction, and the test result was close to the theoretical value. The reaction conditions of $\mathrm{BAF}$ at low temperature $\left(10^{\circ} \mathrm{C}\right)$
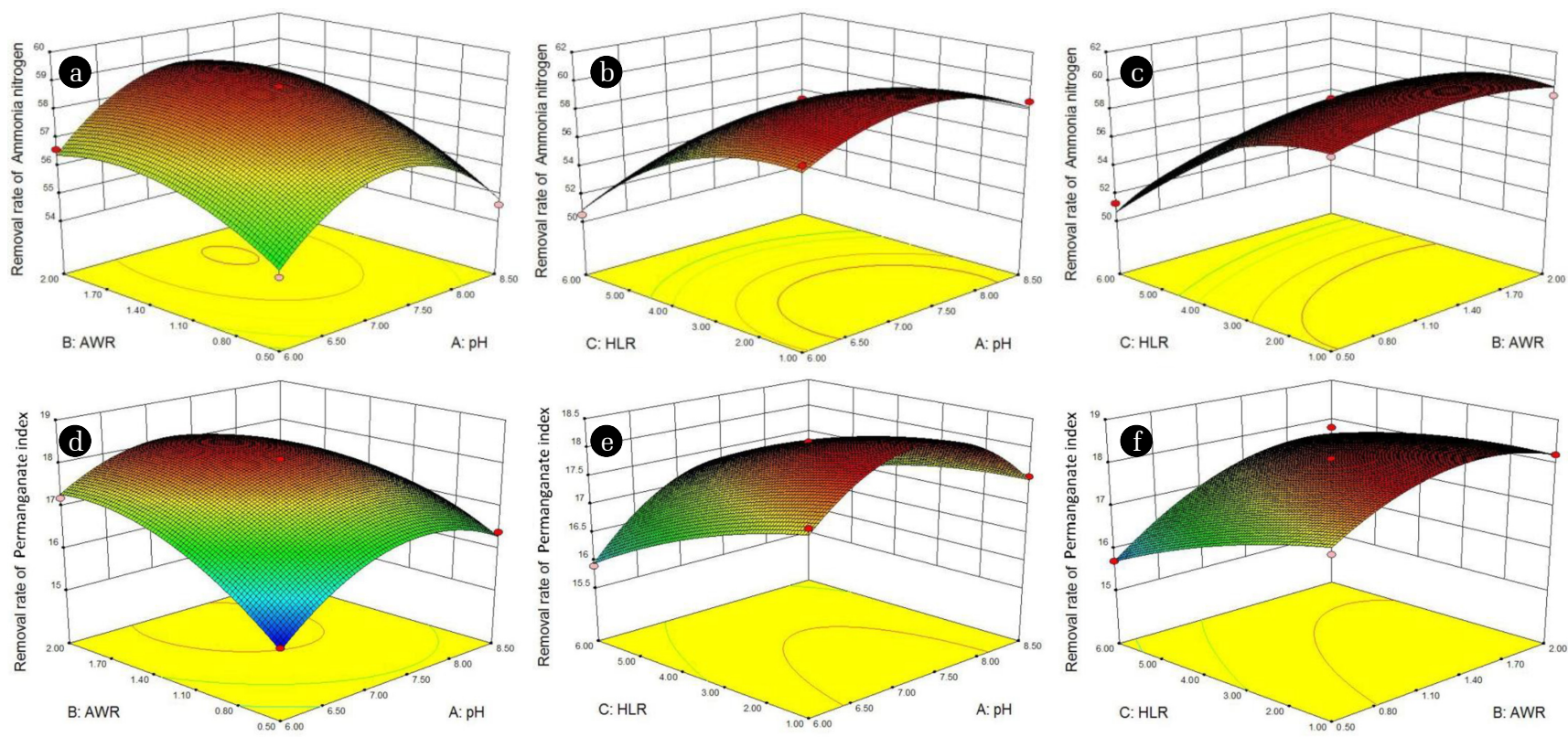

Fig. 5. Response analysis of $\mathrm{pH}, \mathrm{AWR}$ and $\mathrm{HLR}$ to removal rate of pollutants. 
Table 3. Test Results Before and After Response Surface Methodology Optimization

\begin{tabular}{cccccc}
\hline NO. & pH & AWR & HLR & $\mathbf{Y}_{\mathbf{1}}$ & $\mathbf{Y}_{\mathbf{2}}$ \\
\hline 1 & 7.94 & 1.41 & 1.39 & 59.4 & 17.9 \\
2 & 7.94 & 1.41 & 1.39 & 59.3 & 17.7 \\
3 & 7.5 & 2.0 & 1.0 & 58.8 & 17.7 \\
4 & 7.5 & 2.0 & 1.0 & 58.5 & 17.5 \\
\hline
\end{tabular}

optimized by response surface analysis method were accurate and reliable, and had practical value. According to the conclusions of this study, BAF was applied as an emergency treatment device for micro-polluted water in a water treatment plant in a city in northern China, the effluent $\mathrm{NH}_{4}{ }^{+}-\mathrm{N}$ and permanganate index can achieve long-term stability and meet the class water quality standard III in "Environmental Quality Standard for Surface Water" as city water source.

\section{Conclusions}

The BAF can be used as an emergency treatment process for micro-polluted of low-temperature source water. Through experimental verification, the effluent water quality can meet the source water quality standard stably.

For specific source water, the optimal value of main operation management control parameters of BAF can be determined by numerical simulation and using a certain amount of process operation effect data. It has been proved that the response surface test results and the model analysis method fit well with the actual operation effect, and can be used to guide the design and engineering application of BAF.

A river in northern China as water source is selected as the experimental object, under the premise of considering the removal rate of pollutants and saving costs, the optimized model combination conditions are as follows: $\mathrm{pH}$ of 7.94, AWR of 1.41:1.0, HLR of $1.39 \mathrm{~m}^{3} /\left(\mathrm{m}^{2} \mathrm{~h}\right)$, under these conditions, the removal rate of $\mathrm{NH}_{4}{ }^{+}-\mathrm{N}$ is $59.2 \%$, permanganate index is $17.8 \%$.

Using response surface analysis method can achieve the purpose of parameter optimization on the basis of a small amount of experimental data, thus reducing the difficult problems such as long commissioning period and many control variables of water treatment system.

\section{Acknowledgments}

The work is financially supported by national science and technology major project for water pollution control and treatment (2017ZX07501002).

\section{Authors Contributions}

D.L. (Professor) is funding provider, revise the manuscript. X.W. (Ph.D) completed part of the experiment and write the manuscript. X.L. (M.D.) completed part of the experiment. A.W. (Ph.D) revised the manuscript. All authors read and approved the final manuscript.

\section{References}

1. Ziyue Z, Miao Z, Muhammad B, Bo S, Chun Z, Liuna G. MODIS-and CALIPSO-Derived Temporal Aerosol Optical Depth over Yellow River Basin (China) from 2007 to 2015. Earth Syst. Environ. 2020;4(3):535-550.

2. Tawfik AS. Trends in the sample preparation and analysis of nanomaterials as environmental contaminants. Trends Environ. Anal. Chem. 2020;28(2):e00101.

3. Abdullah AA, Mansor BA, Mohd ZH, Nor Ab, Tawfik AS. Copper oxide nanoparticles-loaded zeolite and its characteristics and antibacterial activities. J. Mater. Sci. Technol. 2017;33(8):889-896.

4. Holda P, José Luis P, J Ascención MF, Marcos GM. Effect of Metal Loading in $\mathrm{NiMo} / \mathrm{Al}_{2} \mathrm{O}_{3}$ Catalysts on Maya Vacuum Residue Hydrocracking. Energy Fuels. 2017;31(5):4843-4850.

5. Tawfik AS. Nanomaterials: Classification, properties, and environmental toxicitie. Environ. Technol. Innov. 2020;20(11): 101067.

6. Abdullah AA, Mansor BA, Tawfik AS. Preparation and Characterization of ZeolitelZinc Oxide-Copper Oxide Nanocomposite: Antibacterial Activities. Colloid. Interface Sci. Commun. 2017;1(16):19-24.

7. Abdullah AA, Mansor BA, Tawfik AS, Mohd ZBH, Nor AI. Effect of zinc oxide amounts on the properties and antibacterial activities of zeolite/zinc oxide nanocomposite. Mater. Sci. Eng. C Mater. Biol. Appl. 2016;11(68):505-511.

8. He SB, Xue G, Kong HN. The performance of BAF using natural zeolite as filter media under conditions of low temperature and ammonium shock load. Hazard. Mater. 2007;143:291-295.

9. Zhu J, Lin Y, Wang X, et al. Research progress on nitrogen removal by biological aerated filter. Chem. Eng. Prog. 2017;36(3): 1077-1083.

10. Yin Y, Lu S. Study on modified downflowing BAF for treatment of micro-polluted river water. Technol. Water Treat. 2010;36(11): 78-80,84.

11. Zhang BG, Zhao HZ, Zhou SG, Shi CH, Wang C, Ni JR. A novel UASB-MFC-BAF integrated system for high strength molasses wastewater treatment and bioelectricity generation. Bioresour. Technol. 2009;100:5687-5693.

12. Andersson A, Laurent $P$, Kihn A, et al. Impact of temperature on nitrification in biological activated carbon (BAC) filters used for drinking water treatment. Water Res. 2001;35(12):2923-2934.

13. Hagopian DS, Riley JG. A close look at the bacteriology of nitrification. Aquanclt. Eng. 1998;18(4):223-224.

14. Qu Y, Liu C, Liao R, et al. Comparison of micro-polluted river water treatment by G-BAF and activated sludge process. China Water Wastewater 2010;26(1):60-62

15. Chinese Edition. Water and wastewater analyzing methods. 4th ed. Beijing: China Environmental Science Press; 2002.

16. Kristiana I, Tan J, Joll CA, et al. Formation of N-nitrosamines from chlorination and chloramination of molecular weight fractions of natural organic matter. Water Res. 2013;47(2):535-546.

17. Han M, Zhao ZW, Cui FY, et al. Pretreatment of contaminated raw water by a novel double-layer biological aerated filter for drinking water treatment. Desalin. Water Treat. 2012;37:308-314.

18. Feng Y, Yu YZ, Qiu LP, et al. The characteristics and application of grain-slag media in a biological aerated filter (BAF). Ind. 
Eng. Chem. 2012;18:1051-1057.

19. Ma B, Wang S Y, Cao S B, et al. Biological nitrogen removal from sewage via anammox: recent advances. Bioresour. Technol. 2016;200:981-990.

20. Feng Y, Yu YZ, Qiu LP, et al. Domestic wastewater treatment using biological aerated filtration system with modified zeolite as biofilm support. Desalin. Water Treat. 2014;52:5021-5030.

21. Han SX, Yue QY, Yue M, et al. Effect of sludge-fly ash ceramic particles (SFCP) on synthetic wastewater treatment in an $\mathrm{A} / \mathrm{O}$ combined biological aerated filter. Bioresour. Technol. 2009;100: 1149-1155. 